\author{
MarCIN KuŹMICKI \\ Uniwersytet im. Adama Mickiewicza \\ Instytut Filologii Polskiej \\ ORCID: 0000-0001-6534-3600
}

\title{
Emendacje w tekstach średniowiecznych - problem ich interpretacji i edycji (na przykładzie zapiski sądowej z księgi ziemskiej poznańskiej II)
}

A b strakt: Główny problem przedstawiony w artykule skupia się wokół tytułowego terminu emendacja. Autor przedstawia ów problem z dwóch perspektyw. Pierwsza - to ingerencja średniowiecznego skryby w tekst, czego śladem są skreślenia i korekty wprowadzane przez pisarza. Drugą perspektywą jest działalność badacza-edytora, który odczytuje rękopis, interpretuje go i wydaje, stosując przy tym nieprecyzyjne zasady wydawania, co w konsekwencji prowadzi do zniekształcenia tekstu źródłowego. Przeprowadzone analizy pokazały, że przyjęte zasady wydawania tekstów średniowiecznych powinny być takie, by zachować wszelkie cechy rękopisu, które dotyczą rozumienia tekstu przez pisarza rękopisu, a które są w procesie interpretacji przez współczesnego wydawcę zacierane.

S łow a klucze: wydawanie tekstów średniowiecznych; emendacje; roty sądowe; język staropolski; łacina średniowieczna

Problem poruszony w niniejszym artykule można streścić jednym słowem, będzie nim tytułowa emendacja definiowana w Encyklopedii wiedzy o książce jako: 
Emendacja (łac. emendatio = poprawianie, ulepszenie), wynik jednej z podstawowych czynności edytora-filologa nad krytyką tekstu, zmierzającej w razie stwierdzenia skażeń tekstu do przywrócenia mu kształtu poprawnego, zgodnego $\mathrm{z}$ intencją autora. E. polega na poprawianiu miejsc zniekształconych na podstawie dostatecznie wiarygodnych źródeł (wypowiedzi samego autora, porównanie rpsów, kopii, wydań, przekładu z oryginałem obcojęzycznym, porównanie z materiałem językowym i stylistycznym z innych dzieł pisarza itd.) (Encyklopedia wiedzy o książce 1971, szpalta 669, hasło: emendacja).

Ogólne opracowanie zagadnienia pomyłek pisarskich będzie przedmiotem osobnej pracy, w tym artykule chciałbym się skupić na miejscach, które noszą ślady ingerencji średniowiecznego pisarza w tekst, czyli na skreśleniach i naniesionych $\mathrm{w}$ te miejsca poprawkach oraz na sposobach interpretowania owych emendacji, ich odczytywania, lecz również wydawania przez współczesnych badaczy-edytorów.

Ukazanie owej dwoistości problemu związanego z ingerencją w tekst, czyli z jednej strony wszelkie ślady działalności średniowiecznego skryby (skreślenia, razury, nadpisania), a z drugiej strony decyzje wydawców odnoszące się do tych samych miejsc w rękopisie (paleograficzne pomyłki, błędne interpretacje, posługiwanie się nieprecyzyjnymi zasadami wydawania), stanowią cel niniejszego artykułu. Ze względu na tak zakreślony cel niezbędne jest odwołanie się do źródła, czyli wersji rękopiśmiennej tekstu (skany rękopisu). Wykorzystanie źródła jest niezbędne dla procesu analizy historycznojęzykowej zapisów, które zostały zauważone i skorygowane przez średniowiecznego pisarza, o czym świadczą skreślenia wcześniej zapisanych słów oraz nadpisanie poprawionych wersji. Wgląd w rękopis daje także kontrolę nad tym, co de facto jest i powinno być przedmiotem analizy, a co jest interpretacją wydawcy zależną na przykład od jego kompetencji badawczych. Daje to również możliwość obserwowania efektu pracy średniowiecznych pisarzy, który widoczny jest w postaci bardzo subtelnych emendacji. Doskonałym materiałem do tego typu badań są oczywiście roty sądowe, w których znajduje się spora liczba zarówno błędów, jak i skreśleń czy korekt pisarskich, a jednocześnie są to rękopisy, które stanowią przedmiot zainteresowania badaczy różnych dyscyplin. 
Emendacje w tekstach średniowiecznych

241

1. Materiały stanowiące podstawę źródłową analizy zapiski sądowej $\mathrm{Na}$ potrzeby niniejszego artykułu analizie poddana zostanie jedna zapiska sądowa znajdująca się na karcie 150 recto Księgi sądu ziemskiego w Pozna$\operatorname{niu}(I I)$ :

Rycina 1. Księga sądu ziemskiego w Poznaniu (II), karta 150 recto, fragm.

Chim Ariat. 490 onve hamprisut

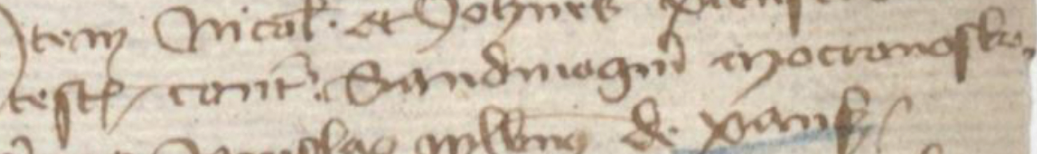

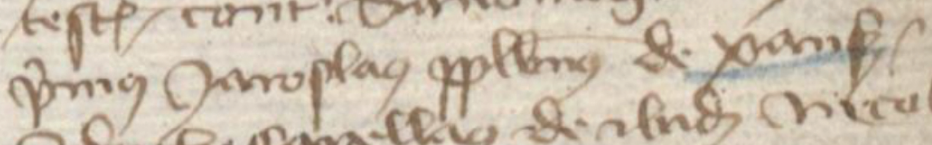

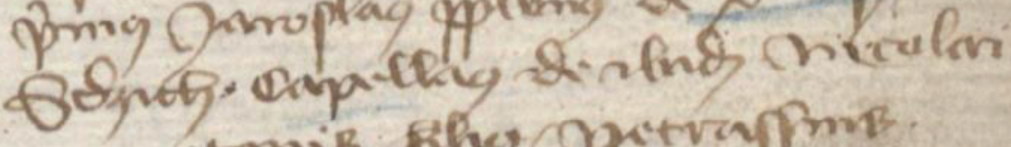

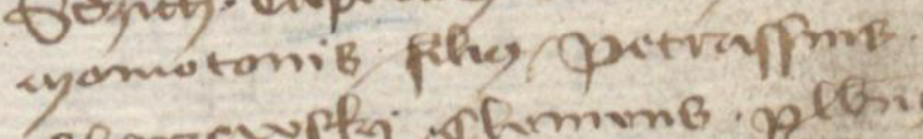

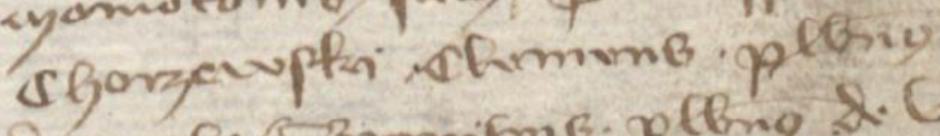

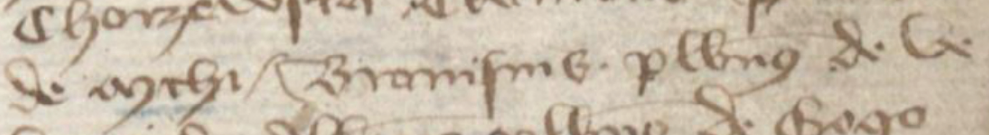

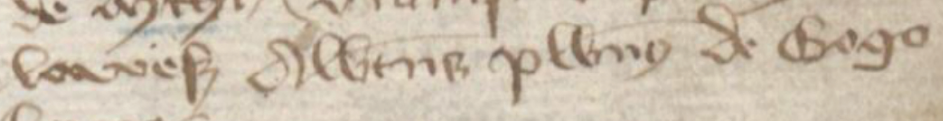
arova

Antzo fjon pamag; bog op ports

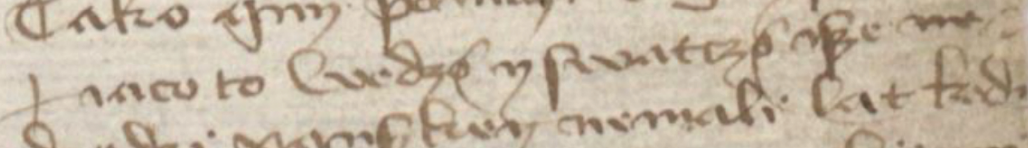

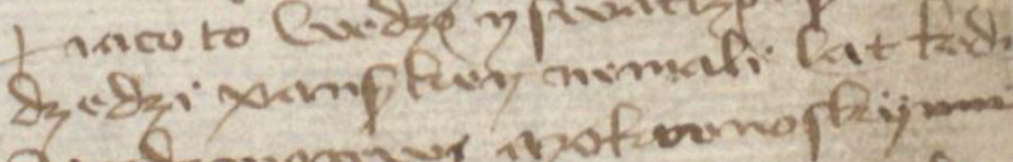

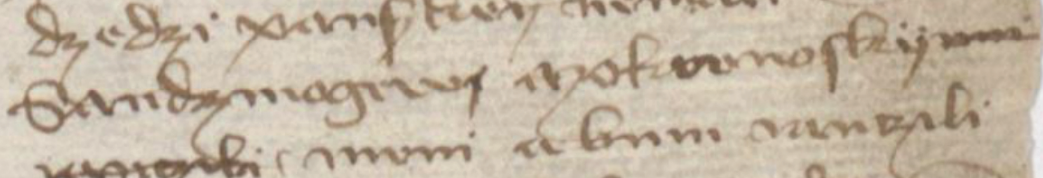
Gobsont trmon at8 minomp mpterenos the 
Rękopis zostanie zestawiony i porównany z dotychczasowymi jego wydaniami, które ukazały się po roku $1955^{1}$. Pod uwagę wzięte zostaną zatem wydania opracowane przez Henryka Kowalewicza i Władysława Kuraszkiewicza (Wielkopolskie roty sądowe XIV-XV wieku, 1959), przez Kazimierza Kaczmarczyka i Karola Rzyskiego (Księga ziemska poznańska 1400-1407, 1960) oraz opracowanie rot w ramach projektu grantowego eROThA, czyli Elektronicznego Repozytorium Rot Wielkopolskich ${ }^{2}$, które jest de facto powieleniem wydania H. Kowalewicza i W. Kuraszkiewicza z drobnymi zmianami, do których przyjdzie jeszcze się odwołać w dalszej części artykułu.

$\mathrm{Na}$ początku zostaną przedstawione poszczególne wydania interesującej nas zapiski w kolejności chronologicznej:

- pierwszym będzie zatem wydanie z roku 1959:

Rycina 2. Zapiska sądowa w opracowaniu H. Kowalewicza i W. Kuraszkiewicza

724. (150) - Item Nicolaus et Johannes Xansei ducit testes contra Sandiuogium Mocronoski: primus Jaroslaus plebanus de Xansz, Sdzich capellanus de ibidem Nicolai Momotonis filius, Petrassius Chorzewski, Clemens plebanus de Mchi, Bronisius plebanus de Velawesz, Albertus plebanus de Gogolewo:

Tako gim pomozi bog yfwãnti $\mid \dagger$ iaco to wedzø y fwatezø ifze [ne】 dzedzi xanfzkey nemali lat kedi $\left.{ }^{1}\right)$

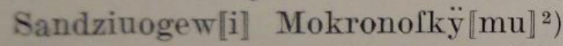
[ranezili], | meni a bimi ranezili Tako jim pomoży Bog i święty $\dagger$, jako to wiedzą i świadezą, iże dzieci Księskiej nie mialy lat, kiedy Sędziwoj[ewi $]^{3}$ ) Mokronoski[emu ręczyły] mieni, aby mu ręezyly.

1) Piek. 446: tedi Sandziwogewj Mokronoskiy .... Abram (lub: meni a brzm).

$\left.{ }^{2}\right)$ Poprawienie $w$ literach r $i \ddot{y}$. Poczqtkowo byto Mokronofkemu.

2) Pisarz skreślil tylko końcowe -i, powinien byl skreślić końcówkę -ewi.

${ }^{1}$ Uwzględnione zostaną tylko te wydania, których data publikacji jest późniejsza od daty ukazania się Zasad wydawania tekstów staropolskich. Projekt (1955). Instrukcje wydawnicze dla średniowiecznych źródeł łacińskich ukazały się wcześniej.

2 eROThA (Elektroniczne Repozytorium Rot Wielkopolskich), ogólnodostępna elektroniczna baza danych powstała w wyniku realizacji projektu badawczego o $\mathrm{nr}$ 2014/13/B/ HS2/00644 finansowanego ze środków Narodowego Centrum Nauki. 
- drugie w kolejności wydanie zostało opracowane przez Kazimierza Kaczmarczyka i Karola Rzyskiego:

Rycina 3. Zapiska sądowa w opracowaniu K. Kaczmarczyka i K. Rzyskiego

1393. Item Nicolaus et Johannes Xansci ducit $(s)$ testes contra Sandiuogium Mocronowski: primus Jaroslaus plebanus de Xansz,. Sdzich capellanus de ibidem, Nicolai Momotonis filius, Petrassius Chorzewski, Clemens plebanus de Mchi, Bronisius plebanus de Velawesz, Albertus plebanus de Gogolewo.

Tako gim pomczi bog y swantit, iaco to wedzø y swatczø, isze ${ }^{a-a}$ dzedzi Xanszey ne meli lat, kedi ${ }^{b-}$ Sandziuogew Mokronos ${ }^{-b}{ }^{c-c}$ meni abum (s) ranczili. Habent terminum ad primos terminos minores iuxta ius terre./

1391. a-a // kal// b-b // wa //

1393. a-a // ne// b-b popr. z Sandzinogewi Mokronoskymu c-c // ranczili// 
- wreszcie wydanie trzecie przygotowane w oparciu o wydanie H. Kowalewicza i W. Kuraszkiewicza w ramach projektu eROThA ${ }^{3}$ :

Rycina 4. Zapiska sądowa opracowana w ramach projektu eROThA

Item Nicolaus et Johannes Xansci ducit testes contra Sandiuogium Mocronoski: primus Jaroslaus plebanus de Xansz, Sdzich capellanus de ibidem Nicolai Momotonis filius, Petrassius Chorzowski, Clemens plebanus de Mchi, Bronisius plebanus de Velawesz, Albertus plebanus de Gogolewo:

Tako gim pomozi bog yiwãnti † iaco to wedzø y rwatczø irze dzedzi xanIzkey nemali lat kedi ${ }^{1}$ Sandziuogewi Mokronorkÿut ${ }^{2}$ meni a bimi ranczili

${ }^{1}$ Piek. 446: tedi Sandziwogewj Mokronoskiy .... Abram (lub: meni a brzm).

${ }^{2}$ Poprawienie w literach r i ÿ. Początkowo było Mokronolkemu.

Tako jim pomoży Bog i święty †, jako to wiedzą i świadczą, iże dzieci Księskiej nie miały lat, kiedy Sędziwoj ${ }^{3}$ Mokronoski mieni, aby mu ręczyły.

${ }^{3}$ Pisarz skreślił tylko końcowe -i, powinien był skreślić końcówkę -ewi.

\section{Część analityczna}

Na wstępie trzeba zaznaczyć, że roty to teksty dwujęzyczne polsko-łacińskie. Dla każdej wersji językowej istnieją osobne zasady opracowywania tekstu oparte na odpowiednich instrukcjach wydawniczych dla źródeł średniowiecznych ${ }^{4}$. Instrukcje te nie są spójne ani pod względem celów, które sobie

3 eROThA (Elektroniczne Repozytorium Rot Wielkopolskich), https://rotha.ehum. psnc.pl/breeze/Pn.724 [dostęp: 24.01.2020].

4 Wciąż podstawowym opracowaniem, gdy chodzi o wydawanie tekstów staropolskich, jest książka Zasady wydawania tekstów staropolskich. Projekt, Wrocław 1955. 
stawiali ich twórcy, ani pod względem zasad, którymi się kierowali; również pod względem stosowania znaków edytorskich są to dwie odrębne tradycje wydawnicze. W przypadku średniowiecznych zapisek sądowych te dwa porządki wydawnicze spotykają się w obrębie jednego tekstu ze wszelkimi tego konsekwencjami. Wszystkie te uwarunkowania należy wziąć pod uwagę, gdy sięga się po roty sądowe .

Główny przedmiot analiz stanowią tzw. błędy oraz ich emendacje znajdujące się w części polskiej zapiski sądowej:

Rycina 5. Księga sądu ziemskiego w Poznaniu (II), karta 150 recto, fragm.

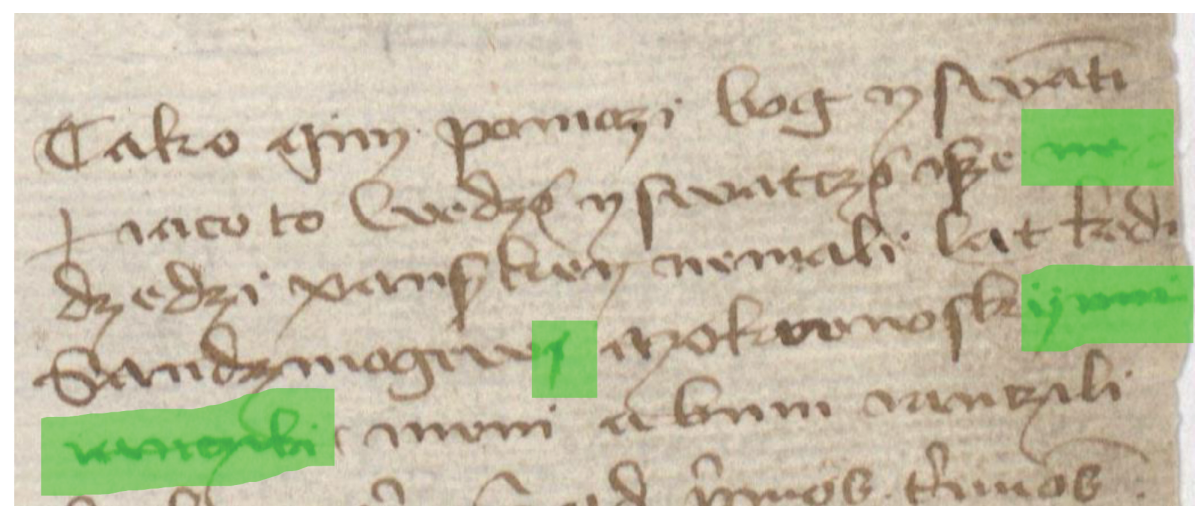

Miejsca znaczone na fotografii zielonym kolorem uwypuklają te fragmenty tekstu, w których skryba poprawiał lub kasował zbędny według niego zapis. Natomiast w wydaniach te partie tekstu opatrzone są odpowiednimi znakami wydawniczymi czy odsyłaczami.

W warstwie treściowej zapiska sądowa nie przedstawia zasadniczo kłopotów interpretacyjnych. Problem pojawia się dopiero wówczas, gdy zadamy sobie pytanie, na ile edytor może ingerować w tekst, by go uczytelnić, uspójnić, niekoniecznie zgodnie z intencją średniowiecznego pisarza. Gdyby po-

Zasady dotyczące wydawania średniowiecznych źródeł łacińskich zostały opracowane już w 1930 roku a rewizji zostały poddane w 1957 roku przez A. Wolffa. Instrukcje te zostały ostatnio ponownie opublikowane w książce Edytorstwo źródet historycznych (Tandecki, Kopiński 2014).

5 Zagadnienie to szczegółowo omawiam w przygotowywanej książce Wydawanie tekstów średniowiecznych jako procedura badawcza. 
nownie odwołać się do Encyklopedii wiedzy o książce, tym razem do hasła edytor, przeczytamy, że jest to „osoba lub zespół ludzi o wykształceniu filologicznym, których zadaniem jest opracowanie do druku poprawnego tekstu cudzego, przy czym za tekst poprawny uważa się tekst zgodny z intencją twórczą jego autora [...]" (Encyklopedia wiedzy o książce, 1971, szpalta 648, hasło: edytor). W przypadku tekstów średniowiecznych spełnienie postulatu poprawności rozumianej jako zgodności z intencją twórczą autora jest trudne, jeśli w ogóle jest realne, chociażby ze względów na brak możliwości osiągnięcia odpowiednich kompetencji, ale jednocześnie powinno to nam uświadomić, że edycja to także procedura badawcza, inicjowana w określonym momencie i trwająca sine fine $e^{6}$.

Wracając do treści zapiski, dowiadujemy się z niej, że: Mikołaj i Jan stawiają świadków przeciwko Sędziwojowi Mokronoskiemu, którym to świadkom niech Bóg pomoże i Święty Krzyż, jako to wiedzą i świadczą, iże ... - w tym miejscu pojawia się pierwsze skreślenie. Pisarz najpewniej chciał zapisać nemali (czyt. nie miały), lecz zorientowawszy się (po wpisaniu już przeczenia), że nie napisał jeszcze, kto nie miał (dziś powiedzielibyśmy, że zabrakło podmiotu), wykreślił owo ne (ne), po czym wrócił do dalszego redagowania zapiski. Jest wielce prawdopodobne, że opracowując rotę na podstawie wcześniej sporządzonych notatek, czyli wersji brudnopiśmiennej, pisarz popełnił tzw. błąd oka i pominął linijkę tekstu. Wracając do treści sprawy: wiedzą i świadczą, że dzieci Księskiej nie miały lat (były niepełnoletnie), aby mu ręczyć ('dawać komuś porękę, zaręczać'). Za takim filologicznym tłumaczeniem opowiadają się wydawcy Kowalewicz z Kuraszkiewiczem, tym samym takie rozumienie proponuje eROThA. Jest jednak drobna, a zarazem fundamentalna różnica pomiędzy obiema transliteracjami. Wydawcy $\mathrm{WRS}^{7}$ posłużyli się w końcowym fragmencie zapiski - a by $\mathrm{m} u$ ręc zyły - kursywą przy formie zaimka 3. osoby sg. w datiwie $(m u)$. Z kolei w eROThA nie ma już śladu po kursywie, czyli nie ma również informacji o tym, że jest to wersja poprawiona przez wydawcę, czyli interpretacja

${ }^{6}$ Celowo nawiązuję do zbioru prac pokonferencyjnych poświęconych edycjom źródeł historycznych, por. Editiones sine fine, K. Kopiński, W. Mrozowicz, J. Tandecki (red.), t. 1, Toruń 2017.

7 (WRS) - tym skrótem określam wydawców Wielkopolskich rot sądowych, czyli W. Kowalewicza i W. Kuraszkiewicza; z kolei (KaczmRzys) to K. Kaczmarczyk, K. Rzyski, Księga ziemska poznańska 1400_1407, Poznań 1960. 
(!) tego fragmentu, a nie forma $\mathrm{z}$ rękopisu. Czytelnik tego wydania jest zdany wyłącznie na swą czujność i konieczność konfrontacji transkrypcji z transliteracją i/lub rękopisem. Nie wiemy, jak dokładnie rozumieli tę zapiskę Kaczmarczyk i Rzyski, ponieważ w wydaniu posługują się oni wyłącznie transliteracją tekstu polskiego. Transliteracja zaś pokazuje nam, w jakim stopniu wydawca opanował sztukę paleografii, lecz nie jest wystarczającym dowodem na zrozumienie tekstu, a owa niepozorna forma zaimka $\mathrm{m} u \mathrm{z}$ kursywną literą $u \mathrm{w}$ transkrypcji wydania WRS jest świadectwem bardzo newralgicznego miejsca w rękopisie:

Rycina 6. Księga sądu ziemskiego w Poznaniu (II), karta 150 recto, fragm.

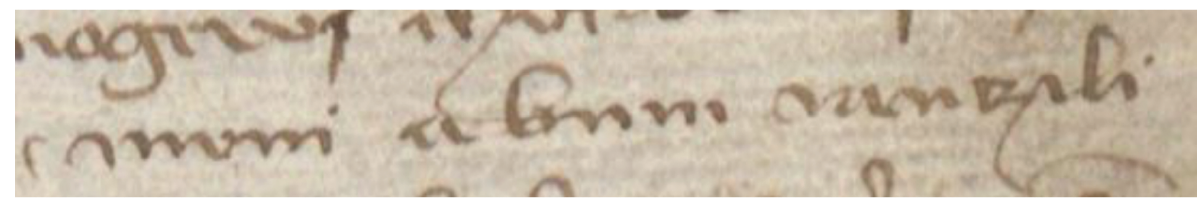

W transliteracji ów fragment przedstawia się następująco:

(WRS) meni a bimi ranczili

(KaczmRzys) meni abum (s) ranczili

(eROThA) meni a bimi ranczili

Czytelne i nie wzbudzające wątpliwości są zatem litery $a, b$, choć to, czy zostały one zapisane łącznie, czy też rozdzielnie, nie jest już tak jednoznaczne i bezdyskusyjne. Nie ma natomiast wątpliwości co do tego, że dalej następuje pięć kresek, którym trzeba nadać sens. W tym miejscu dochodzimy do istoty transkrypcji, w której to wydawca musi (powinien) zdecydować, w jaki sposób opowie tę historię. Kuraszkiewicz zdecydował się na kursywę. Zapewne wiedział, że brakuje w tym miejscu w rękopisie jednej kreseczki, która dzieliła go od sensu (abi mu - 6 kresek), z podobnych względów Kaczmarczyk i Rzyski postawili w transliteracji w nawiasie kursywne (s), niejako na znak kapitulacji, oznaczając formę błędną, niezrozumiałą, pozostawiając czytelnika bez jakiejkolwiek wskazówki. Niezrozumiała będzie tylko decyzja o usu- 
nięciu kursywy z transkrypcji w edycji (eROThA), ale i to można podciągnąć pod nieuważne przepisywanie czy błąd na etapie redakcyjnym.

Pozostawmy błędy, które dostrzegli wydawcy, by powrócić do skreśleń, które wprowadził manu propria średniowieczny pisarz. Oto one raz jeszcze:

Rycina 7. Księga sądu ziemskiego w Poznaniu (II), karta 150 recto, fragm.

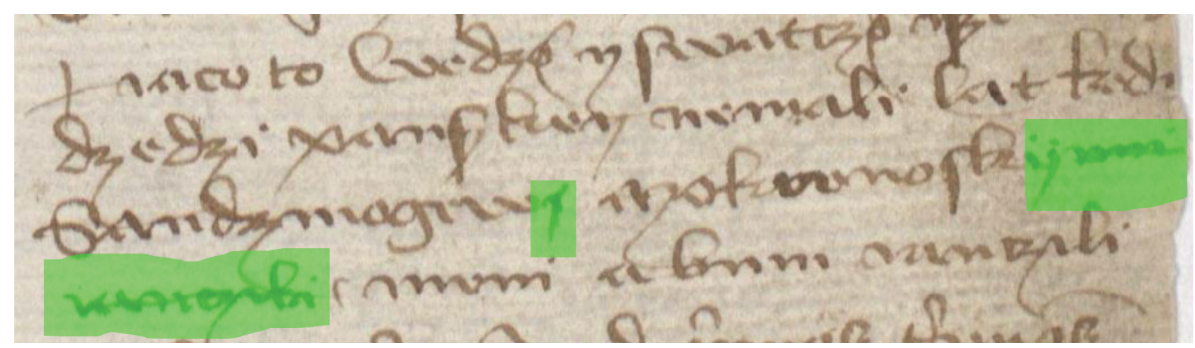

Wprowadzone przez pisarza emendacje tworzą następującą treść:

dzieci Księskiej nie miały lat, kiedy Sędziwojew Mokronoski mieni - dalej następują znane nam już problemy - ... aby mu ręczyły.

Co jednak by się stało, gdybyśmy przywrócili „pierwotny” tekst, czyli tę wersję sprzed naniesionych przez średniowiecznego skrybę poprawek:

dzieci Księskiej nie miały lat, kiedy Sędziwojewi Mokronoskiemu ręczyly |... mieni aby mu ręczyly.

Przede wszystkim okazuje się, że tekst jest całkowicie czytelny i gramatycznie poprawny, ze wzorcowym zdaniem czasowym i dopełnieniem w datiwie, co więcej, zapiska ta mogłaby się w tym miejscu zakończyć bez najmniejszej utraty sensu (dlatego też wprowadzona została cezura w postaci pionowej kreski; nie jest to znak edytorski oznaczający koniec wiersza). Z jakiegoś powodu stało się inaczej. Coś innego musiało być istotniejsze niż wyrażona już poprawnie gramatycznie i logicznie treść. Jakie zatem zaszły zmiany? Pierwsze dwie emendacje to przesunięcie Sędziwoja z pozycji dopełnienia, czyli z pozycji obiektu czynności wyrażonego datiwem, na pozycję podmio- 
tu (w nominatiwie), tym samym uczynienie z niego sprawcy czynności. Nieważne zatem jest to, że Mokronoskiemu dzieci ręczyły, tylko istotnym staje się to, co ma robić, mianowicie mienić, czyli 'wypowiadać swoje zdanie; twierdzić coś' (Słownik staropolski, t. 4, z. 3(22), 226-230). Dlatego też pojawiło się trzecie skreślenie. Wszystkie trzy przeprowadzone korekty miały na celu oddać głos Sędziwojowi Mokronoskiemu, czyli wprowadzić jego wypowiedź w postaci oratio recta. Przesunięty zostaje tym samym akcent z opisu sytuacji prawnej na rzecz przytoczenia bardzo konkretnej wypowiedzi, jednocześnie strukturyzowanie zdania ustępuje mowie niezależnej (mówioności):

dzieci Księskiej nie miały lat, kiedy Sędziwojew Mokronoski mieni: aby mi ręczyty.

Zmiany, które zostały wprowadzone przez pisarza, można by określić jako minimalne, lecz konieczne. Nie wykreślił bowiem pisarz wcześniejszego fragmentu - nie miały lat - gdyż pociągałoby to za sobą dalsze niezbędne poprawki. Można wskazać jeszcze jedną zaletę takiej interpretacji:

Rycina 8. Księga sądu ziemskiego w Poznaniu (II), karta 150 recto, fragm.

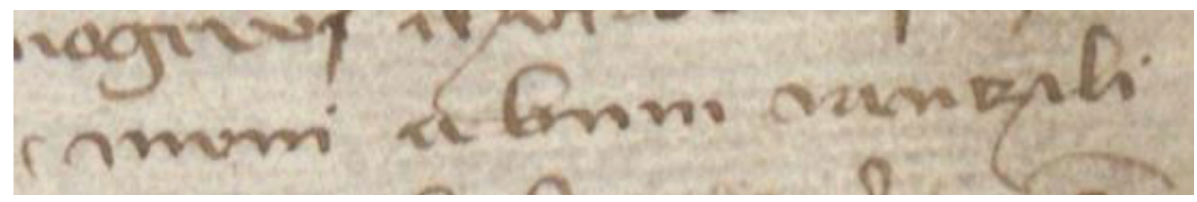

Chodzi oczywiście o ingerencję wydawcy w tekst, konieczność jego naprawiania, by uzyskać sensowne odczytanie. W tym konkretnym przypadku przy zaproponowanym odczytaniu i interpretacji możemy mówić o braku jakiejkolwiek ingerencji w tekst. Nie ma bowiem konieczności wmawiania pisarzowi błędu (kursywa w formie zaimka „m $u$ ” czy kursywne $s$ w nawiasie okrągłym $)^{8}$, zwłaszcza w tak uważnie i starannie sporządzanej zapisce.

${ }^{8} \mathrm{Na}$ marginesie rozważań chciałbym zwrócić uwagę na pewien aspekt wydania (KaczmRzys), chodzi o sprowadzenie wszelkich skreśleń do przypisów. W omawianym 
By rozwiać wszelkie niejasności dotyczące wydanego tekstu i różnic pomiędzy wydaniami, należy powrócić do celowo pominiętej formuły przysięgi: Tako jim pomoży Bog $i$ święty †. Tym razem rzecz dotyczy poziomu transliteracji tekstu. Jak już wspomniałem wcześniej, zarówno filolodzy, jak i historycy mają odrębne instrukcje wydawnicze, którymi się posiłkują przy wydawaniu źródeł średniowiecznych. $Z$ tego też powodu nie zawsze możliwe jest zestawianie wydań wywodzących się z odmiennych tradycji badawczych. Tak się dzieje właśnie w tym przypadku, gdy będziemy chcieli wskazać na relację rękopis-wydanie w zakresie sposobu oznaczania abrewiacji. Historycy zgodnie z zaleceniami instrukcji wydawniczych wszelkie pojawiające się w rękopisie skróty rozwiązują w wydaniu bez jakiejkolwiek komentarza czy znaku edytorskiego (informacja na temat stosowania takiej praktyki może pojawić się jedynie we wstępie do wydania). Nie ma zatem możliwości, by czytelnik bez sięgnięcia każdorazowo do rękopisu miał jakiekolwiek wyobrażenie o pojawiających się co rusz abrewiacjach w rękopisie, będzie to dla niego terra incognita. W wydaniu WRS, w transliteracji widnieje następujący zapis: y $\int \mathrm{w} a ̃ \mathrm{n} t \mathrm{i}$. Jest on powtórzony w dokładnie tej samej formie w (eROThA). W rękopisie natomiast wyraz ten został zapisany w taki oto sposób:

Rycina 9. Księga sądu ziemskiego w Poznaniu (II), karta 150 recto, fragm.

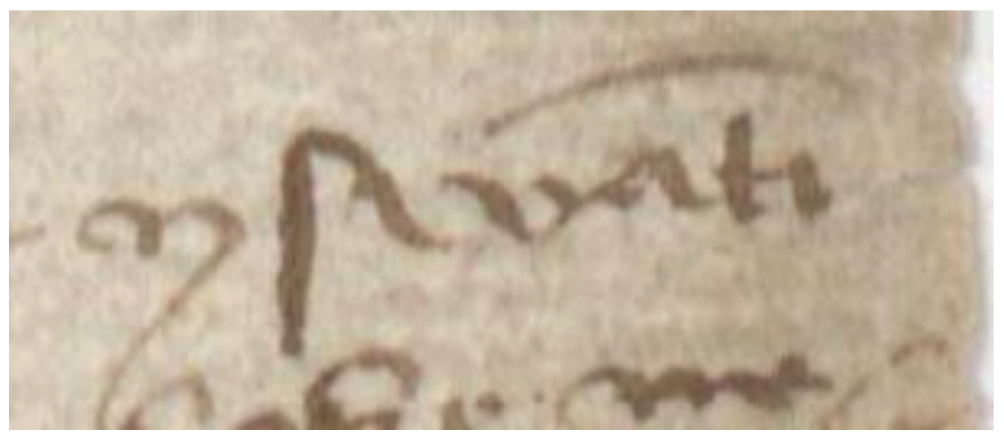

przykładzie ten sposób wydania paradoksalnie uniemożliwił, a przynajmniej znacząco utrudnił zrozumienie tekstu, choć miało to służyć jego przejrzystości. 
Czyli mamy do czynienia $\mathrm{z}$ typową abrewiacją, w której łuk nadpisany nad częścią wyrazu oznacza, że należy ten wyraz uzupełnić o literę $n$ lub $m$, w tym przypadku chodzi oczywiście o literę $n$. Zasady wydawania tekstów staropolskich zalecają rozwiązywać takie skróty poprzez zaznaczenie brakujących liter górną frakcją, czyli tak: yfwanti. Wydawcy WRS być może chcieli zaznaczyć fakt pojawiającej się abrewiacji w tym miejscu, specjalną czcionką „ã”, lecz niefortunnie umieścili obok jeszcze literę $n$, która wprawia czytelnika w konfuzję, gdyż nie wie on, czym jest owo $a$, skoro niczego w tym wyrazie nie brakuje. Kuraszkiewicz z Kowalewiczem opracowywali i wydawali te zapiski pod koniec lat pięćdziesiątych XX wieku, więc porównując ówczesne możliwości techniczne wspomagające redaktorów i wydawców w ich pracy ze współczesnymi udogodnieniami, należy uznać, że pojawiające się pomyłki w wydaniu WRS są stosunkowo nieliczne. Zastanawiające natomiast jest ich powielanie w XXI wieku, w czasach, gdy każdy może na swoim ekranie komputera otworzyć daną kartę rękopisu i zweryfikować odczytania, zwłaszcza tak specyficzne, jak to z literą ã, a jednak w edycji (eROThA) w transliteracji powtórzono ten zapis, uchybiając zasadom wydawania, a przede wszystkim rękopisowi.

Jeśli chodzi o część łacińską zapiski, zasadniczo nie ma różnic pomiędzy wydaniami, pomijając może błędne odczytanie czy, co bardziej prawdopodobne, literówkę przy przepisywaniu powstałą w nazwie osobowej Chorzewski. Na stronie projektu eROThA widnieje bowiem ta nazwa zapisana przez $o$ Chorzowski, z pewnością nie było to odczytanie konfrontowane z rękopiśmiennym zapisem, który przedstawia się następująco:

Rycina 10. Księga sądu ziemskiego w Роznaniu (II), karta 150 recto, fragm.

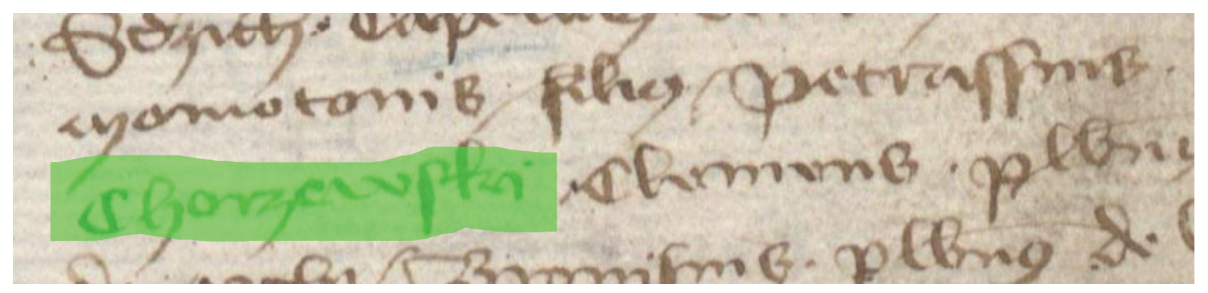

Pozostałe dwa wydania idą zgodnie za średniowiecznym zapisem Chorzewski. Drugą różnicą jest wprowadzenie przez K. Kaczmarczyka i K. Rzyskie- 
go komentarza (litery $s$ ujętej w nawias okrągły) do formy ducit zwracającego uwagę na niepoprawną formę czasownika - Item Nicolaus et Johannes Xansci ducit ( $s$ ). Nie dziwi fakt, że wydawcy wskazują na błędną formę czasownika, ponieważ to nie Jan wprowadza świadków, lecz obaj bracia, zatem oczekiwalibyśmy formy pluralnej czasownika ( $d u$ cunt). Jan i Mikołaj Ksiąscy to bracia i jednocześnie synowie Ochny, czego można się dowiedzieć z indeksu do tego wydania ${ }^{9}$. O ile we wcześniejszym wydaniu nie dostrzeżono, nie skomentowano tej nieścisłości, o tyle w najnowszej wersji wydania (eROThA) można by już oczekiwać jakiejkolwiek refleksji nad tym fragmentem, której ślad pozostałby choćby w komentarzu.

Ostatnią różnicą, którą można wskazać pomiędzy wydaniami, jest obecność na końcu zapiski łacińskiego fragmentu dotyczącego ustalenia terminu. Passus ten pojawia się tylko w wydaniu K. Kaczmarczyka i K. Rzyskiego, co nie jest zaskoczeniem, ponieważ wydawcy ci ze znacznie większą pieczołowitością podchodzą do części łacińskiej niż pozostali, mający na celu przede wszystkim wydanie tekstu polskiego, a nie zapiski sądowej jako pewnej całości:

Rycina 11. Księga sądu ziemskiego w Poznaniu (II), karta 150 recto, fragm.

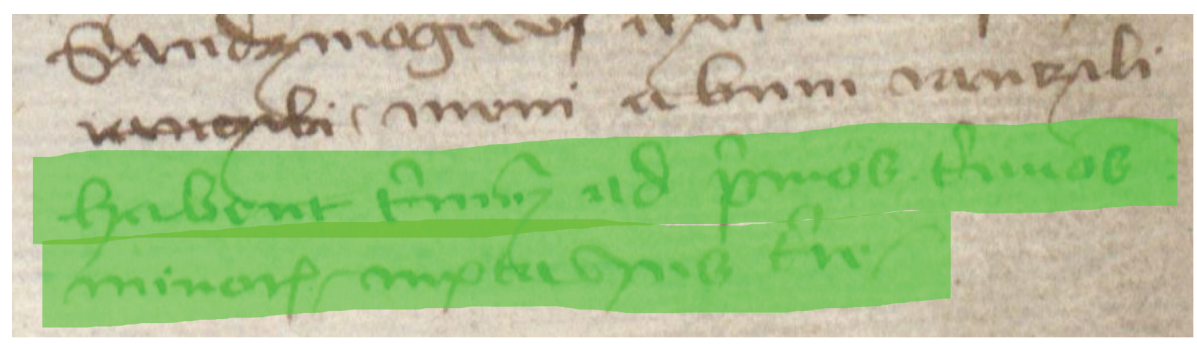

Oto transliteracja znajdującego się powyżej łacińskiego fragmentu zapiski sądowej:

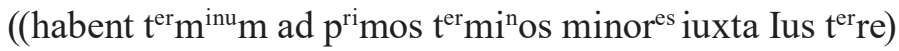

9 Hasło: Książ w: Indeks do Księgi ziemskiej poznańskiej 1400-1407 (Kaczmarczyk, Rzyski 1960: 515-516). 
Nie stoi nic na przeszkodzie, by wydać tę rotę w sposób najbliższy manuskryptowi, na przykład tak:

Tabela 1. Propozycja transliteracji oraz transkrypcji zapiski sądowej z karty 150 recto

\begin{tabular}{|c|c|}
\hline TRANSLITERACJA & TRANSKRYPCJA \\
\hline 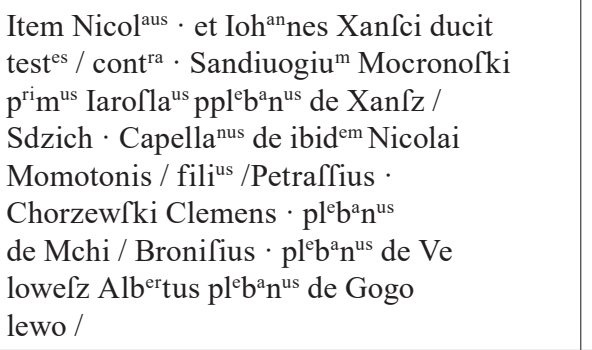 & $\begin{array}{l}\text { Item Nicolaus et Johannes Xansci ducunt } \\
\text { testes contra Sandiuogium Mocronoski: } \\
\text { primus Jaroslaus plebanus de Xansz, Sdzich } \\
\text { capellanus de ibidem, Nicolai Momotonis } \\
\text { filius Petrassius Chorzewski, Clemens } \\
\text { plebanus de Mchi, Bronisius plebanus de } \\
\text { Velowesz, Albertus plebanus de Gogolewo: }\end{array}$ \\
\hline 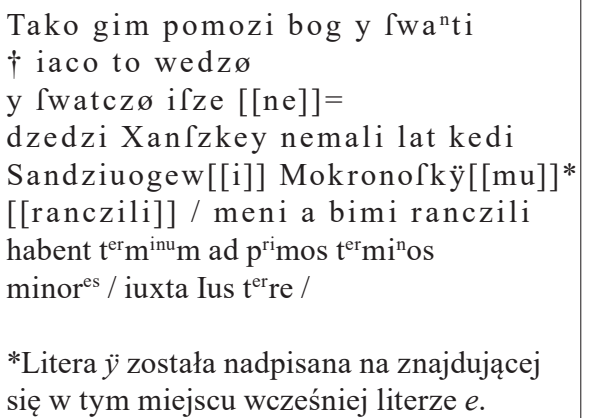 & $\begin{array}{l}\text { Tako jim pomoży Bog i święty } \\
\text { †, jako to wiedzą i świadczą, iże } \\
\text { dzieci Księskiej nie miały lat, } \\
\text { kiedy Sędziwoj* Mokronoski } \\
\text { mieni: „aby mi ręczyły”. } \\
\text { Habent terminum ad primos terminus } \\
\text { minores iuxta ius terre. } \\
\text { *Skryba pozostawił zapis Sędziwojew, } \\
\text { najprawdopodobniej zapomniał wykreślić } \\
\text { także końcowe -ew. }\end{array}$ \\
\hline
\end{tabular}

Źródło: opracowanie własne.

W przedstawionej powyżej propozycji transliteracji oraz transkrypcji można zauważyć zasadnicze zmiany względem dotychczasowych praktyk wydawniczych. Najistotniejsze z nich to przede wszystkim wprowadzenie rozróżnienia pomiędzy transliteracją i transkrypcją dla wersji łacińskiej, wbrew powszechnej praktyce i przekonaniu, że różnice pomiędzy nimi są nieznaczące, co w konsekwencji prowadzi do przyjęcia przez wydawców uwspółcześnionego zapisu. Nie sposób wówczas dostrzec wszelakich kwestii związanych chociażby z użyciem wielkich liter czy znaków delimitacji tekstu. Ta druga kwestia pomijana jest również w transliteracji tekstu polskiego. Warto zwrócić uwagę na część polską właśnie ze względu na jednokrotne po- 
jawienie się znaku delimitacyjnego i to w bardzo newralgicznym miejscu tekstu, chodzi oczywiście o fragment, który skryba poprawiał, by móc wprowadzić wypowiedź w postaci oratio recta. Znaczenie i funkcja tych znaków nie zostanie poznana, jeśli wydania konsekwentnie będą tę warstwę pomijać. W konsekwencji tych działań i całej przedstawionej procedury badawczej można wprowadzić odpowiednią interpunkcję w transliteracji, oddającą i sens, i strukturę składniową zapiski, co przywraca jej wartość jako podstawie badań semantycznych i składniowych, które, jak wiadomo, prowadzone są na transkrypcjach ${ }^{10}$.

\section{Podsumowanie}

Przedstawione analizy miały na celu ukazanie dwoistości problemu związanego $\mathrm{z}$ ingerencją $\mathrm{w}$ tekst. Wszelkie emendacje, po których pozostaje w rękopisie ślad, jak na przykład skreślenia, stanowią wyraz pewnej refleksji średniowiecznego pisarza w jego pracy nad tekstem. Czasami będą to zwyczajne korekty np. powtórzonych omyłkowo wyrazów, innym razem owe emendacje będą miały znacznie głębszy sens i trudniej będzie uchwycić ich przyczynę. Prowadzi to tym samym do drugiego aspektu problemu, mianowicie do ingerencji wydawców w opracowywany tekst. Zdarza się, że ingerencja jest na tyle znacząca, że prowadzi do błędnych decyzji i zmienia sens wydawanego tekstu albo/i uniemożliwia pełne wykorzystanie informacji zawartych $\mathrm{w}$ tekście. Z każdą z tych sytuacji mieliśmy do czynienia $\mathrm{w}$ analizowanej zapisce sądowej:

- począwszy od prostego błędu, jakim było zbyt wczesne zapisanie przeczenia (ne) przez średniowiecznego skrybę, czy omyłkowego wpisania w wydaniu WRS po literze ã litery $\mathbf{n}$, która symbolicznie zawiera się w nadpisanej falce nad literą a;

- przez emendacje, które ujawniają swój sens dopiero wówczas, gdy przeanalizuje się je w kontekście całej zapiski (zmiana form datiwu na nominatiwus i wprowadzenie oratio recta);

${ }^{10}$ Na temat znaczenia prawidłowego rozpoznania znaków delimitacyjnych w tekście staropolskim i konieczności zmiany podejścia do interpunkcji wprowadzanej do transkrypcji napisano w ostatnim czasie niemało. Por. np. (Mika 2017: 199-208; Mika, Ziółkowska 2017: 105-125). 
- wreszcie błędne odczytania abum w wydaniu (KaczmRzys), brak transkrypcji tekstu polskiego, przez co nie wiadomo, jak wydawcy rozumieli wydawany tekst (KaczmRzys), czy błędna decyzja o wprowadzeniu formy zaimka $m u$ bez oznaczenia kursywy w transkrypcji (eROThA), co całkowicie zafałszowuje obraz i znaczenie tekstu;

- na koniec, wszelkie decyzje podjęte w zakresie konwencjonalizacji zapisu: czy to będzie uwspółcześnianie pisowni wielkich i małych liter, czy pisownia łączna i rozdzielna form przyimkowych lub partykuł, czy nieoznaczanie pojawiających się w tekście abrewiacji, czy wreszcie brak oddawania średniowiecznych znaków delimitacji tekstu wszystkie te decyzje pozbawiają badaczy możliwości śledzenia jakichkolwiek zjawisk z nimi związanych.

W świetle powyższych ustaleń wyraźnie rysuje się perspektywa badawcza. Niezbędne będzie zatem opisanie rozmaitych błędów oraz ich emendacji, z którymi spotyka się badacz średniowiecznych rękopisów, począwszy od tych typowych, znanych i odnotowanych w literaturze (np. tzw. błędy oka), jak również tych błędów, które są wynikiem rozproszenia uwagi danego pisarza, i których przyczyn powstania najpewniej nigdy nie poznamy; wreszcie takich pomyłek, które wskazują na pewną świadomość pisarską czy nawet redaktorską, gdyż wprowadzane przez średniowiecznego skrybę różnego rodzaju korekty odnoszą się właśnie do poszczególnych etapów redakcji tekstu. Wszelkiego rodzaju emendacje, ich specyfika wskazuje na pisarskie predylekcje, na podstawie których można ustalać zwyczaje pisowniane, można wykazać, że istniało coś takiego jak średniowieczne decorum. Trzeba tylko uważniej wczytywać się w rękopis i nie tracić go z oczu, gdy przechodzimy do jego wydawania. Każdy popełnia błędy i żadne wydanie nie będzie od nich wolne, czego najlepszym przykładem jest przedstawione krytyczne ujęcie wydań na przykładzie zapiski sądowej z karty 150 recto. Jednak w przewrotny sposób doszło do sytuacji, w której ów drobiazg w postaci jednej małej kreseczki, a ściśle braku jednej kreseczki w rękopisie, którego dopatrywali się wydawcy, doprowadził tych samych wydawców do pomyłki. Od starożytności wszakże wiadomo, że problemem nie jest pomyłka, lecz jej powielanie: Errare humanum est, sed in errare perseverare diabolicum. 


\section{Zdjęcia i skany dostępne online}

Ksiega sadu ziemskiego w Poznaniu, [online] https://rotha.ehum.psnc.pl/breeze/ Pn.724 [dostęp: 13.02.2020].

Księgi sadu ziemskiego w Poznaniu, sygn. 53/9/0/-/2, [online] https://szukajwarchiwach.pl/53/9/0/-/2/str/1/1/30\#tabJednostka [dostęp: 13.02.2020].

\section{Wydania}

eROThA (Elektroniczne Repozytorium Rot Wielkopolskich), ogólnodostępna elektroniczna baza danych powstała $\mathrm{w}$ wyniku realizacji projektu badawczego nr 2014/13/B/HS2/00644 finansowanego ze środków Narodowego Centrum Nauki.

Księga ziemska poznańska 1400-1407, wyd. K. Kaczmarczyk, K. Rzyski, Poznań 1960.

Wielkopolskie roty sqdowe $X I V-X V$ wieku, t. 1, roty poznańskie, zebr. i oprac. H. Kowalewicz, W. Kuraszkiewicz, Poznań-Wrocław 1959.

\section{Slowniki i leksykony}

Birkenmajer A., Kocowski B., Trzynadlowski J. (red.), 1971, Encyklopedia wiedzy o książce, Wrocław-Warszawa-Kraków.

Jougan A., 1958, Stownik kościelny łacińsko-polski, Poznań-Warszawa-Lublin.

SONDEL J., 2003, Stownik tacińsko-polski dla prawników i historyków, [CD-ROM], Kraków: UNIVERSITAS.

UrbaŃcZYK S. (red.), 1953-2007, Stownik staropolski, t. 1-11, Wrocław-Warszawa-Kraków.

\section{Bibliografia}

AdamsKa A., 2011, Czy potrzebna nam jest społeczna historia języka?, w: S. Gawlas (red.), Historia społeczna późnego średniowiecza. Nowe badania, Warszawa: Wydawnictwo DiG, s. 189-202.

Dymmel P., 2001, Bibliografia edytorstwa źródet historycznych w Polsce. Historia - krytyka tekstu - metodyka i technika wydawnicza, Lublin: Wydawnictwo Uniwersytetu Marii Curie-Skłodowskiej.

GéHIN P. (red.), 2008, Jak czytać rękopis średniowieczny, Warszawa: Oficyna Wydawnicza „Mówią Wieki”.

GóRsKi K., 1978, Tekstologia i edytorstwo dziet literackich, Warszawa: PWN. 
JUReK T., 2011, Pismo w życiu społecznym Polski późnego średniowiecza, w: S. Gawlas (red.), Historia społeczna późnego średniowiecza. Nowe badania, Warszawa: Wydawnictwo DiG, s. 203-231.

JureK T. (red.), 2014, Dyplomatyka staropolska, Warszawa: Wydawnictwo DiG.

KozAK A., 2017, W poszukiwaniu metody edycji późnośredniowiecznych kościelnych źródeł sądowych, w: K. Kopiński, W. Mrozowicz, J. Tandecki (red.), Editiones sine fine, t. 1, Toruń: Towarzystwo Naukowe w Toruniu, s. 163-175.

KuraszKiEWICZ W., 1986, Zapiski i roty polskie w księgach sądowych warszawskich XV-XVI wieku, w: W. Kuraszkiewicz, Polski język literacki. Studia nad historia i struktura, Warszawa-Poznań: PWN, s. 558-564.

KurAszKiewiCz W., 1986, Brudnopisy i czystopisy rot kościańskich, w: W. Kuraszkiewicz, Polski język literacki. Studia nad historia i struktura, Warszawa-Poznań: PWN, s. 565-578.

KURASZKIEWICZ W., 1986, Formuły przysięgi w rotach sądowych XV-XVI wieku, w: W. Kuraszkiewicz, Polski język literacki. Studia nad historia i struktura, Warszawa-Poznań: PWN, s. 579-587.

Łosowski J., 2017, Problem modernizacji instrukcji wydawniczej dotyczącej źródeł historycznych z okresu staropolskiego, w: K. Kopiński, W. Mrozowicz, J. Tandecki (red.), Editiones sine fine, t. 1, Toruń: Towarzystwo Naukowe w Toruniu, s. $227-243$.

Mika T., 2017, Na obrzeżach pewnego poletka, czyli o znakach nielubianych przez edytorów tekstów dawnych, w: B. Hojdis, K. Krzak-Weiss (red.), Co musi wiedzieć uczony edytor, nawet jeśli nie chce. Prace ofiarowane Profesorowi Wiesławowi Wydrze, Poznań: Poznańskie Studia Polonistyczne, s. 199-208.

MıkA T., ZıóŁkowska O., 2017, Jak wprowadzać interpunkcję do tekstu staropolskiego?, w: K. Borowiec, D. Masłej, D. Rojszczak-Robińska (red.), Staropolskie spotkania językoznawcze 2. Jak wydawać teksty dawne, Poznań: Rys, s. 105-125.

SŁoń M., 2017, Sine initio et sine fine. Edycja źródła jako proces zawsze otwarty, w: K. Kopiński, W. Mrozowicz, J. Tandecki (red.), Editiones sine fine, t. 1, Toruń: Towarzystwo Naukowe w Toruniu, s. 131-141.

SŁoń M., SŁomski M., 2017, Edycje cyfrowe źródeł historycznych, w: K. Borowiec, D. Masłej, D. Rojszczak-Robińska (red.), Staropolskie spotkania językoznawcze 2. Jak wydawać teksty dawne, Poznań: Rys, s. 65-84.

StęPlewski A., 2013, Pismo i pisarze w średniowiecznej Polsce. Grafia wielkopolskich rot sadowych, Poznań: Rys.

TANDECKi J., KoPIŃSKi K., 2014, Edytorstwo źródeł historycznych, Warszawa: Wydawnictwo DiG.

WoronczaK J., Górski K. (red.), 1955, Zasady wydawania tekstów staropolskich. Projekt, Wrocław: Zakład im. Ossolińskich, Wyd. Polskiej Akademii Nauk. 


\section{Emendations in medieval texts - \\ the problem of their interpretation and editing \\ (on the example of the court record from the Poznań Land Book II) \\ ( su m mary)}

The main problem presented in the article and its title revolves around the term emendation. The author presents this problem from two perspectives. The first is the interference of the medieval scribe into the text which is evidenced by the deletions and corrections introduced by the writer. The second perspective is the activity of the researcher-editor who reads the manuscript, interprets, and publishes it, using imprecise publishing rules. This, in turn, leads to a distortion of the source text. The conducted analyzes showed that the adopted principles of publishing medieval texts should be such as to preserve all the features of the manuscript that relate to the writer's understanding of the text, and which are blurred in the process of interpretation by a modern publisher.

Ke y w ord s: publishing of medieval texts; emendation; court case; Old Polish; medieval Latin 